\title{
The Levels of Using Strategic Management Tools and Satisfaction with Them: A Case of Five-Star Hotels in Turkey
}

\author{
Ali Erbaş ${ }^{1} \&$ Şafak Ünüvar ${ }^{2}$ \\ ${ }^{1}$ Vocational School of Social Sciences, Selcuk University, Konya, Turkey \\ ${ }^{2}$ School of Tourism and Hotel Management, Selcuk University, Konya, Turkey \\ Correspondence: Ali Erbaşı, Vocational School of Social Sciences, Selcuk University, Campus of Alaeddin \\ Keykubat, Selçuklu/Konya, Turkey. Tel: 90-332-223-2293. E-mail: aerbasi@selcuk.edu.tr
}

Received: July 23, 2012 Accepted: August 8, 2012 Online Published: October 16, 2012

doi:10.5539/ijbm.v7n20p71 URL: http://dx.doi.org/10.5539/ijbm.v7n20p71

\begin{abstract}
The main purpose of this research is to determine the levels of using strategic management tools (SMT) and satisfaction with them in five star hotels in Turkey. In addition, the relationships between the characteristics of managers and organizations in terms of using the SMT and satisfaction with term are investigated. The sample includes 53 five-star hotels in Turkey. Results show that the levels of using SMT are high, but satisfactions with them are low. While the tool with the highest usage is customer relationship management, the tool with the lowest usage is Hoshin Kanri. On the other hand, while the SMT of Swot Analysis has highest satisfaction scores, the Search conference has lowest. Thus, a matrix of the levels of using SMT and satisfaction with term is presented. In this study, significant differences among organizations' operation years and their decision making levels in terms of using SMT are determined. No significant differences are determined among all demographic characteristics in terms of satisfaction with the SMT.
\end{abstract}

Keywords: strategic management tools, swot, customer relationship management, five star hotels

\section{Introduction}

A search for making short term and medium term plans and their planning procedures to reach long term targets brings the importance of strategic management tools into the prominence. Therefore, in recent years, strategic management tools are highly preferred in many application areas. In this view, it is possible to come across with many studies in the literature on the application of various strategic management tools in hotel managements. For instance, Kaplan and Norton (1996) suggest a balanced scorecard as a strategic management tool to transfer long-term strategies into short-term actions. Koszevska (2004) examines the current situation of outsourching as a modern management strategy in protective clothing market. Dogan and Demiral (2008: 1-22) examine the benchmarking technique, which is defined as an important tool to increase the efficacy of strategic management. It is possible to increase these samples. However, there is very little research, which evaluates all strategic management tools in the literature. In these studies, findings on the usage of strategic management tools and techniques or of satisfaction levels resulting from their usage in the managements are mentioned. In one of these, Sucu (2010) investigates the applications of strategic management tools in small and medium sized enterprises and concludes to what extent the strategic management tools are used here. The study is conducted in 55 medium sized enterprises currently carrying on their business in İzmir (the number of personnel is between 50-249). As a result of the study, it is emphasized that the strategic management tools are not known by medium sized enterprises and also they are not used. The most common tools and techniques, claimed to be in use by managements, which participated in the survey, are determined as benefit-cost analysis, risk analysis, total quality management and portfolio analysis.

Pasanen (2011: 1-8) conducts a research to determine the usage and satisfaction levels of strategic management tools in 143 small and medium sized enterprises in Finland. 15 strategic management tools and techniques are tested in 101 service managements and 42 production managements. As a result, the usage and satisfaction levels of strategic management tools in small and medium sized enterprises make a difference when compared to large managements. Besides, a significant resolution is observed between the usage and satisfaction levels of strategic management tools in small and medium sized enterprises in production and service sectors and strategic management tools. Fowzia (2010) conducts a study on determining the usage levels of strategic management 
accounting techniques in production managements in Bangladesh. As a result, it is emphasized that the acceptance levels of strategic management accounting techniques are not satisfactory in production managements and several tools come into the prominence during performance development process.

Jack (2009) conducts a field research on the usage of strategic management accounting tools in agriculture and agricultural industry. Such evaluations on the usage of tools as benchmarking, balanced scorecard, supply chain management, Porter's competition analysis and target cost management, are involved in the research, conducted in England, United States, Australia and New Zealand. Erbaşı (2012) determines the levels of knowledge and importance of 35 strategic management tools in five star hotel managements about the same sample in Turkey in his study. As a result, it is seen that the most common and most-valued strategic management tool by the managers is determined as customer relationship management, the least common as gordon technique and the less valued as search conference. In this study, it was determined that the higher the level of knowledge for strategic management tools, the more importance the managers give these tools. Çakıcı (1998) describes in his study that importance of customer relationship management one of the strategic management tools for hotel enterprises by a descriptive study. Rigby (2001: 139-160) investigates the usage and satisfaction levels of strategic management tools in 15 countries over four continents, carrying their business on different sectors. As a result, it is seen that the successful companies use strategic management tools more than unsuccessful ones. Besides, financially successful companies are determined to have much higher satisfaction levels on the usage of strategic management tools than the unsuccessful ones.

Cinquini and Tenucci (2007) conducts a study on the usage of 14 strategic management accounting tools in 93 companies, currently carrying their business on different sectors in Italy. By using a 5-item Likert type scale in the study, they determine 7 tools having an average usage of more than 3 . They also determine by developing 5 hypotheses that there is no significance in the rate of usage of tools and techniques in terms of the size of the management. On contrary to this conclusion, Gulding (1999) concludes that there is a significant resolution between the rate of usage of tools and techniques and the size of the management and also this rate in large managements is much higher than the small managements.

There is very little research in the literature on determining the usage levels of strategic management tools in managements and their satisfaction. As understood from the sample, a small number of strategic management tools are of our focus. However, strategic management tools are not limited so and the usage of other management tools in other studies plays an important role in terms of the significance of the results. Also, there is no research in the literature review on investigating the usage of strategic management tools in five star hotels in Turkey taking as a sample. In this view, it is highly important to determine the usage and satisfaction levels basing on several strategic management tools in five star hotels in Turkey in terms of revealing the current situation in five star hotel managements.

\section{Research Methodology}

The context of the study involves all 328 five star hotels currently carrying their business in Turkey according to the 2010 data (Republic of Turkey, Ministry of Culture and Tourism. 2011: 11). All managements are contacted by phone and the surveys prepared are sent to the responsible managers via mail by the researchers. However, 275 of these managements do not response back for several reasons although they are delivered in advance. The sample of the research involves 53 five star hotel managements by which the survey is received and answered back. In this view, $16.2 \%$ of five star hotel managements in Turkey are conferred. Initially, a pilot application is made in 10 managements, picked randomly from the sample and several determinations are made about the statements in the survey. For these determinations, an information note including some conceptual terms on strategic management tools and techniques is also prepared and delivered together with the surveys in order to increase the understandability of the survey. Also, the survey is finalized by adding some conceptual equivalents (English equivalents in some) to increase the understandability of strategic management tools in terms of these determinations.

In this three-part survey, the first part involves 10 demographic questions about the management and the second involves 7 demographic questions about the manager who completes the survey. The third part investigates the usage and satisfaction levels of 30 strategic management tools and techniques. The strategic management tools are taken as basis from the studies by Fleisher and Bensoussan (2002), Chak (1998: 4), Akgemci (2008: 47-124), Kocer (2007: 81), Aktan (2006: 171-173), Sucu (2010: 121), Senturk (2010: 35), Pasanen (2011: 1-8), Aktan (2008: 7-9), Yilmaz (2007: 57-69) and Erdogan (2008: 37-44). Two different 5-item Likert type scale is used for the responses of participants in the survey. The scale involves items from (1) Always (2) Often (3) Mostly (4) to Sometimes (5) Never when evaluating the usage levels of strategic management tools. The scale involves items 
from (1) Very Good (2) Good (3) Little (4) Very Little to (5) Never when determining the satisfaction levels of application results. The reliability coefficient is determined to be .994 , which is calculated via internal consistency method of Cronbach Alpha by excluding 5 items from the 35-item strategic management tool in the survey. This rate indicates that the reliability of these scales is quite high. The survey is applied in October, November and December in 2011 and the results obtained are analyzed via SPSS 16.0 packet program.

The number of strategic management tools is not limited only in the 30 ones used in our study. This model involving any strategic search and effort for increasing the efficacy of the management can be classified as strategic management tool. This case may be accepted as a limitation for our study. Another limitation is that only 53 hotel managements are contacted in the context of 328. By the participation of more management, the results would be more significant. However, the number of samples is still able to represent the context in terms of statistics.

\section{Findings}

In the study, managers from 53 managements are asked to answer the questions on demographic characteristics firstly of the management and then of the manager. The $41.5 \%$ of managements in the study have a capital more than 15 million TRY. $88.7 \%$ of participant managements have a domestic capital; $56.6 \%$ have a sales turnover more than 7 million TRY; $58.5 \%$ have an annual number of customers more than 10.000; and when the number of personnel is taken into consideration, $3.8 \%$ involves small scaled, $62.3 \%$ medium scaled and $33.9 \%$ of large scaled managements. The data on the demographic characteristics of participant managements are given in Table 1.

Table 1. The demographic characteristics of participant managements

\begin{tabular}{|c|c|c|c|c|c|}
\hline Variables & $N=53$ & $\%$ & Variables & $N=53$ & $\%$ \\
\hline Operation Years & & & Capitalization & & \\
\hline $2-3$ years & 5 & 9.4 & Less than 1 million TL & 4 & 7.5 \\
\hline 4-7 years & 14 & 26.4 & 1-3 million TL & 14 & 26.4 \\
\hline $8-15$ years & 18 & 34.0 & 3-7 million TL & 3 & 5.7 \\
\hline $16-24$ years & 11 & 20.8 & 7-15 million TL & 10 & 18.9 \\
\hline 25 years and more & 5 & 9.4 & More than 15 million TL & 22 & 41.5 \\
\hline Total Income for the Last Year & & & Total Giro for The Last Year & & \\
\hline Less than 1 million TL & 10 & 18.9 & Less than 1 million TL & 3 & 5.7 \\
\hline 1-3 million TL & 19 & 35.8 & 1-3 million TL & 10 & 18.9 \\
\hline 3-7 million TL & 13 & 24.5 & 3-7 million TL & 10 & 18.9 \\
\hline 7-15 million TL & 10 & 18.9 & 7-15 million TL & 17 & 32.1 \\
\hline More than 15 million TL & 1 & 1.9 & More than 15 million TL & 13 & 24.5 \\
\hline $\begin{array}{c}\text { The Total Number of Customers for the } \\
\text { Last Year }\end{array}$ & & & The Number of Stakeholders & & \\
\hline Less than 1000 & 3 & 5.7 & 1 & 23 & 43.4 \\
\hline $1001-2000$ & 5 & 9.4 & 2 & 10 & 18.9 \\
\hline $2001-5000$ & 4 & 7.5 & $3-4$ & 8 & 15.1 \\
\hline $5001-10000$ & 10 & 18.9 & 5 & 9 & 17.0 \\
\hline More than 10000 & 31 & 58.5 & $6-9$ & 2 & 3.8 \\
\hline & & & 100 and more & 1 & 1.9 \\
\hline Number of Staff & & & Number of Trained Staff (about tourism) & & \\
\hline Less than 50 & 2 & 3.8 & $6-10$ & 5 & 9.4 \\
\hline $50-249$ & 33 & 62.3 & $11-20$ & 10 & 18.9 \\
\hline $250-499$ & 14 & 26.4 & $21-40$ & 22 & 41.5 \\
\hline 500-999 & 4 & 7.5 & 41 and more & 16 & 30.2 \\
\hline
\end{tabular}




\section{Strategic Management Decisions by Whom}

Included middle-level management

Included middle and lower level of

management

Participation of all staff

Type of Property

Independent Hotel

Hotel Chain

\section{Personnel' Education Levels}

$\begin{array}{ccc}\text { Primary Education } & 40 & 75.5 \\ \text { Undergraduate } & 12 & 22.6 \\ \text { Post-Undergraduate } & 1 & 1.9\end{array}$

Hotel Type

Business Hotel

$11 \quad 20.8$

Health Hotel

$2 \quad 3.8$

Resting Hotel

In the study, $81.8 \%$ of the managers filling in the survey are male, $86.8 \%$ of them are managers, $79.2 \%$ of them are undergraduate and $50.9 \%$ of them are at the age of 36 or above. The demographic characteristics of managers filling in the survey on behalf of their participant managements are given in Table 2.

Table 2. The demographic characteristics of managers filling in the survey

\begin{tabular}{cccccc}
\hline Variables & $\mathbf{N}=\mathbf{5 3}$ & $\mathbf{\%}$ & Variables & $\mathbf{N}=\mathbf{5 3}$ & $\mathbf{\%}$ \\
\hline Gender & & & Professional Experience & & \\
Male & 43 & 81.1 & $1-5$ years & 11 & 20.8 \\
Female & 10 & 18.9 & $6-10$ years & 16 & 30.2 \\
Position & & & $11-15$ years & 10 & 18.9 \\
Director of Finance & 4 & 7.5 & $16-20$ years & 10 & 18.9 \\
Director of F\&B & 2 & 3.8 & 21 years and more & 6 & 11.3 \\
General Manager & 18 & 34.0 & Age & & \\
Director of Front-office & 15 & 28.3 & $18-25$ & 2 & 3.8 \\
Director of Accounting & 7 & 13.2 & $26-30$ & 6 & 11.3 \\
Assistant General Manager & 7 & 13.2 & $31-35$ & 18 & 34.0 \\
Education Level & & & $36-45$ & 21 & 39.6 \\
Primary Education & 2 & 3.8 & $46-55$ & 6 & 11.3 \\
Undergraduate & 42 & 79.2 & & & \\
Post-Undergraduate & 9 & 17.0 & & &
\end{tabular}

The average of usage levels of strategic management tools by five star hotel managements in Turkey is 1.5844 . The average of satisfaction levels of 30 hotel managers using strategic management tools is determined as 3.8077. The findings of average usage and satisfaction levels of five star hotel managements in Turkey on 30 strategic management tools are given in Table 3.

Table 3. The average of usage and satisfaction levels of strategic management tools

\begin{tabular}{cccc}
\hline & $\mathbf{n}$ & Mean & Std. Deviation \\
\hline Average of Usage & 53 & 1.5844 & .72432 \\
Average of Satisfaction & 30 & 3.8077 & .49926 \\
\hline
\end{tabular}

When the usage levels of 30 strategic management tools in five star hotel managements in Turkey are examined, it is observed that the most frequently used strategic management tool is the method of customer relationship management. This method is followed by vision/mission statements, risk analysis and open group discussions, respectively. The least frequently used strategic management tool is hoshin kanri method. This method is 
followed by McKinsey matrix, q-sort analysis and nominal group technique, respectively. The average usage levels of each strategic management tool are given in Table 4.

Table 4. The average of usage levels of strategic management tools

\begin{tabular}{|c|c|c|}
\hline $\mathbf{n}=\mathbf{5 3}$ & Mean & Std. Deviation \\
\hline Open Book Management & 1.53 & 1.067 \\
\hline Open Group Discussions & 2.09 & 1.319 \\
\hline Search Conference & 1.30 & .890 \\
\hline Balanced Scorecard & 1.36 & 1.039 \\
\hline Brain Storming & 1.98 & 1.394 \\
\hline Value Chain Analysis & 1.47 & .992 \\
\hline Reengineering & 1.26 & .763 \\
\hline Outsourching & 1.62 & 1.078 \\
\hline E-trade & 1.92 & 1.542 \\
\hline Benefit-Cost Analysis & 1.98 & 1.575 \\
\hline Hofer Analysis (Product/ Market Assessment Matrix) & 1.34 & 1.018 \\
\hline Hoshin Kanri & 1.09 & .450 \\
\hline Quality Circles & 1.79 & 1.350 \\
\hline Benchmarking & 2.06 & 1.562 \\
\hline Downsizing & 1.49 & 1.187 \\
\hline McKinsey Matrix & 1.15 & .533 \\
\hline Multivoting & 1.23 & .609 \\
\hline Customer Relationship Management & 2.57 & 1.824 \\
\hline Nominal Group Technique & 1.19 & .735 \\
\hline Learning Organizations & 1.58 & 1.134 \\
\hline Organizational Development & 1.64 & 1.226 \\
\hline Porter's Competitive Analysis & 1.34 & .876 \\
\hline Portfolio Analysis & 1.85 & 1.406 \\
\hline Q-sort Analysis & 1.17 & .727 \\
\hline Risk Analysis & 2.23 & 1.577 \\
\hline Scenario Analysis & 1.74 & 1.318 \\
\hline Strategic Total Quality Management & 2.04 & 1.519 \\
\hline Swot Analysis & 1.68 & 1.356 \\
\hline Supply Chain Management & 1.77 & 1.310 \\
\hline Vision/Mission Statements & 2.26 & 1.595 \\
\hline
\end{tabular}

When the satisfaction levels of managements using strategic management tools are examined, it is seen that the Swot analysis is the most satisfied tool. This method is followed by customer relationship management, e-trade and benchmarking, respectively. The least satisfaction level of tools at the end of their usage is determined as search conference. This method is followed is McKinsey matrix, downsizing and outsourching, respectively. The average satisfaction levels for each strategic management tool are shown in Table 5. 
Table 5. The average satisfaction levels of strategic management tools

\begin{tabular}{|c|c|c|c|}
\hline & $\mathbf{n}$ & Mean & Std. Deviation \\
\hline Open Book Management & 14 & 3.36 & 1.151 \\
\hline Open Group Discussions & 26 & 3.50 & .762 \\
\hline Search Conference & 12 & 2.75 & 1.422 \\
\hline Balanced Scorecard & 8 & 3.88 & .835 \\
\hline Brain Storming & 23 & 3.91 & .733 \\
\hline Value Chain Analysis & 11 & 3.55 & .934 \\
\hline Reengineering & 7 & 3.43 & .976 \\
\hline Outsourching & 17 & 3.18 & .951 \\
\hline E-trade & 17 & 4.41 & .795 \\
\hline Benefit-Cost Analysis & 17 & 4.06 & .827 \\
\hline Hofer Analysis (Product/ Market Assessment Matrix) & 7 & 4.00 & 1.000 \\
\hline Hoshin Kanri & 4 & 3.25 & 1.258 \\
\hline Quality Circles & 17 & 3.59 & 1.121 \\
\hline Benchmarking & 20 & 4.30 & .733 \\
\hline Downsizing & 11 & 3.00 & 1.265 \\
\hline McKinsey Matrix & 5 & 3.00 & 1.581 \\
\hline Multivoting & 8 & 3.50 & 1.069 \\
\hline Customer Relationship Management & 25 & 4.48 & .770 \\
\hline Nominal Group Technique & 4 & 4.00 & .816 \\
\hline Learning Organizations & 14 & 3.64 & 1.151 \\
\hline Organizational Development & 13 & 4.08 & .641 \\
\hline Porter's Competitive Analysis & 8 & 3.62 & .916 \\
\hline Portfolio Analysis & 15 & 4.27 & .594 \\
\hline Q-sort Analysis & 3 & 3.67 & 1.528 \\
\hline Risk Analysis & 21 & 4.14 & .573 \\
\hline Scenario Analysis & 15 & 4.07 & .799 \\
\hline Strategic Total Quality Management & 19 & 4.21 & .787 \\
\hline Swot Analysis & 11 & 4.64 & .674 \\
\hline Supply Chain Management & 15 & 3.87 & .834 \\
\hline Vision/Mission Statements & 22 & 4.14 & .710 \\
\hline
\end{tabular}

The results indicate that brain storming, e-trade, benefit-cost analysis, benchmarking, customer relationship management, organizational development, portfolio analysis, risk analysis, scenario analysis, strategic total quality management, swot analysis, supply chain analysis and vision/mission statements have low levels of usage and high levels satisfaction; and outsourching, quality circles and learning organizations have high usage levels and low satisfaction levels. Besides, balanced scorecard, Hofer analysis and nominal group techniques have low usage but high satisfaction levels; and open book management, search conference, supply chain analysis, reengineering, hoshin kanri, downsizing, McKinsey matrix, multivoting, Porter's competition analysis and q-sort analysis have low usage but high satisfaction levels. A usage-satisfaction matrix is prepared in Table 6, basing on the average usage and satisfaction levels of strategic management tools in five star hotel managements in Turkey. 
Table 6. The matrix for the usage and satisfaction levels of strategic management tools

\begin{tabular}{cll}
\hline Usage-Satisfaction Matrix & \multicolumn{1}{c}{$\begin{array}{c}\text { High Satisfaction } \\
\text { (Above Average: 3,8077) }\end{array}$} & \multicolumn{1}{c}{$\begin{array}{c}\text { Low Satisfaction } \\
\text { (Below Average: 3,8077) }\end{array}$} \\
\hline & - Brain Storming & \\
- E-trade & - Benefit-Cost Analysis \\
& - Benchmarking & \\
- Customer Relationship Management & - Open Group Discussions \\
High Usage & - Organizational Development & - Outsourching \\
(Above Average: 1.5844) & - Portfolio Analysis & - Quality Circles \\
& - Risk Analysis & - Learning Organizations \\
& - Scenario Analysis & \\
& - Strategic Total Quality Management & \\
& - Swot Analysis & \\
& - Supply Chain Management & \\
& - Vision/Mission Statements & - Open Book Management \\
& & - Search Conference \\
& & - Value Chain Analysis \\
& & - Reengineering \\
Low Usage & - Balanced Scorecard & - Hoshin Kanri \\
& - Nominal Group Technique & - Downsizing \\
& & - McKinsey Matrix \\
& & - Multivoting \\
& & - Porter's Competitive Analysis \\
& &
\end{tabular}

In the study, it is also determined whether there is a significant difference among some demographic characteristics on the usage and satisfaction levels of strategic management tools in five star hotel managements in Turkey. Therefore, 12 hypotheses have been prepared. The non-parametric tests are used for the first 8 hypotheses where the data have a normal distribution; and parametric tests are used for the other 4 hypotheses where the data have a normal distribution. Hypotheses and their results are given in Table 7.

Table 7. Hypotheses and their results

\begin{tabular}{|c|c|c|c|c|}
\hline Hypotheses & Test & $\mathbf{p}$ & $\begin{array}{l}\text { Rejected / } \\
\text { Accepted }\end{array}$ & Conclusion \\
\hline $\begin{array}{l}\text { H1: Strategic management tools } \\
\text { vary in accordance with the } \\
\text { years spent in the sector. }\end{array}$ & $\begin{array}{c}\text { Kruskal } \\
\text { Wallis }\end{array}$ & .03 & Accepted & $\begin{array}{l}\text { The usage levels of strategic managemen } \\
\text { tools of the managements running more thar } \\
25 \text { years are high when compared to the } \\
\text { others. }\end{array}$ \\
\hline $\begin{array}{l}\mathrm{H} 2 \text { : The usage levels of } \\
\text { strategic management tools } \\
\text { vary in net profit of the } \\
\text { previous year. }\end{array}$ & $\begin{array}{c}\text { Kruskal } \\
\text { Wallis }\end{array}$ & .71 & Rejected & $\begin{array}{l}\text { There is no significant difference between } \\
\text { the usage levels of strategic management } \\
\text { tools and net profit of the previous year. }\end{array}$ \\
\hline $\begin{array}{l}\text { H3: The usage levels of } \\
\text { strategic management tools } \\
\text { vary in hotel types in } \\
\text { possession. }\end{array}$ & $\begin{array}{l}\text { Mann-W } \\
\text { hitney U }\end{array}$ & .210 & Rejected & $\begin{array}{l}\text { There is no significant difference between } \\
\text { the usage levels of strategic management } \\
\text { tools and hotel types in possession. }\end{array}$ \\
\hline
\end{tabular}


H4: The usage levels of strategic management tools vary in total number of personnel.

H5: The usage levels of strategic management tools vary in the average education levels of the personnel.

H6: The usage levels of strategic management tools vary in hotel type.

H7: The usage levels of strategic management tools vary in the number of educated personnel in tourism in hotel management.

H8: The usage levels of strategic management tools vary in the decision-making levels of strategic management.

H9: The satisfaction levels of strategic management tools vary in total number of personnel.

H10: The satisfaction levels of strategic management tools vary in the average education levels of the personnel.

H11: The satisfaction levels of strategic management tools vary in the number of educated personnel in tourism and hotel management.

H12: The satisfaction levels of strategic management tools vary in the decision-making levels of strategic management.

\section{Kruskal \\ Wallis}

.27 Rejected

Kruskal

Wallis

Kruskal

Wallis

.25

Rejected

Kruskal

Wallis

.99

Rejected

Kruskal

Wallis

.01 Accepted

Anova

.82

Rejected

Anova

\section{Rejected}

Anova

.0861 Rejected

Anova

.0954 Rejected
There is no significant difference between the usage levels of strategic management tools and total number of personnel.

There is no significant difference between the usage levels of strategic management tools and the average education levels of the personnel.

There is no significant difference between the usage levels of strategic management tools and hotel type.

There is no significant difference between the usage levels of strategic management tools and the number of educated personnel in tourism in hotel management.

The usage levels of strategic management tools are high where the decisions are made by the participation of all personnel.

There is no significant difference between the satisfaction levels of strategic management tools and total number of personnel.

There is no significant difference between the satisfaction levels of strategic management tools and the average education levels of the personnel.

There is no significant difference between the satisfaction levels of strategic management tools and the number of educated personnel in tourism and hotel management.

There is no significant difference between the satisfaction levels of strategic management tools and the decision-making levels of strategic management.

\section{Conclusion}

The views from 53 five star hotel managements are taken into consideration in our study, in which we try to determine the usage and satisfaction levels of strategic management tools in five star hotel managements in Turkey. According to the results of the analysis, the average usage levels of strategic management tools are low (1.5844) but satisfaction levels are high (3.8077). The most frequently used strategic management tool in five star hotel managements in Turkey is determined as customer relationship management; the least frequently used tool is hoshin kanri, the most satisfying tool is swot analysis and the least satisfying is search conference. According to the usage and satisfaction matrix prepared by basing on the usage and satisfaction levels of strategic management tools, brain storming, e-trade, benefit-cost analysis, benchmarking, customer relationship management, organizational development, portfolio analysis, risk analysis, scenario analysis, strategic total quality management, swot analysis, supply chain analysis and vision/mission statements have low levels of usage but high levels satisfaction; and open group discussions, outsourching, quality circles and learning organizations have high levels of usage but low levels of satisfaction. Besides, balanced scorecard, Hofer 
analysis and nominal group technique have low usage but high satisfaction levels; and open book management, search conference, supply chain analysis, reengineering, hoshin kanri, downsizing, McKinsey matrix, multivoting, Porter's competition analysis and q-sort analysis have low usage but high satisfaction levels.

A significant difference is observed between the years spent in the sector by the managements and decision-making levels of strategic management tools and the usage levels of strategic management tools in the analysis made by non-parametric tests. The usage levels of strategic management tools in five-star hotel managements in Turkey vary according to the net profit of the previous year, hotel types in terms of possession, total number of personnel, the average education levels of the personnel, hotel types and the number of educated personnel in tourism and hotel management. The satisfaction levels in terms of strategic management tools in five star hotel managements in the analysis made by parametric tests vary according to total number of personnel, the average education levels of the personnel, the number of educated personnel in tourism and hotel management and the decision making levels of strategic management tools. These data do not indicate a significant difference between satisfaction levels of strategic management tools and demographic variables. We believe that the results obtained from the study are important in terms of reflecting the situation on the usage and satisfaction levels of strategic management tools in five star managements in Turkey. In addition, the study plays an important role in giving a light to the usage and satisfaction of strategic management tools in the hotel managements.

\section{References}

Akgemci, T. (2008). Stratejik Yönetim (Yenilenmiş 2. Baskı). Ankara: Gazi Kitabevi.

Aktan, Coşkun C. (2006). Stratejik Yönetim ve Stratejik Planlama (İçinde: Kamu Mali Yönetiminde Stratejik Planlama ve Performans Esaslı Bütçeleme, Editör: Coşkun Can Aktan). Ankara: Seçkin Yayınları, s. 167-204.

Aktan, Coşkun C. (2008). Stratejik Yönetim ve Stratejik Planlama. Çimento Işsveren Dergisi, 22(4), 4-21.

Chak, Chiew M. (1998). Strategic Management for Small and Medium Enterprises. British: St Clements University.

Cinquini, L., \& Andrea T. (2007). Is the adoption of Strategic Management Accounting Techniques Really "Strategy-driven"? Evidence from a Survey. Cost and Performance In Services And Operations Trento (Italy), June(18-20), 1-27.

Çakıcı, A. Celil. (1998). Otel İşletmeciğinde Müşteri Tatmin Düzeylerinin 'Değerlendirme Formları' Kullanılarak Belirlenmesi. Anatolia: Turizm Araştırmaları Dergisi, 9(Eylül-Aralık), 9-16.

Doğan, Selen ve Demiral, Özge (2008). İşletmelerde Stratejik Yönetimin Etkinliğini Artırmada Önemli Bir Araç: Benchmarking. ZKÜ Sosyal Bilimler Dergisi, 4(7), 1-22.

Erbaş1, Ali. (2012). The Levels of Knowledge and Importance of Strategic Management Tools in Five-Star Hotel Managements in Turkey. International Review of Business and Social Sciences, 1(5), 61-69.

Erdoğan, Didem D. (2008). Stratejik Yönetim ve Kurumsallaşma Üzerindeki Etkisi: Bankacılık Alanında Bir Uygulama. Yüksek Lisans Tezi, Gazi Üniversitesi Sosyal Bilimler Enstitüsü, Ankara.

Fleisher, Craig S., \& Babette E. B. (2002). Strategic and Competitive Analysis: Methods and Techniques for Analyzing Business Competition. Prentice Hall: The MindShifts Group Pty Ltd.

Fowzia, R. (2010). Influence of Strategic Management Accounting Techniques on Performance Improvement in Manufacturing Organizations of Bangladesh. Proceedings of 4th Annual Asian Business Research Conference held at the BIAM Foundation in Dhaka (23-24 December 2010), World Business Institute, Melbourne, Australia.

Guilding C. (1999). Competitor-Focused Accounting: An Exploratory Note. Accounting Organizations and Society, 24(7), 583-595. http://dx.doi.org/10.1016/S0361-3682(99)00007-0

Jack, L. (2009). The Adoption of Strategic Management Accounting Tools in Agriculture Post Subsidy Reform: A Comparative Study of Practices in the UK, the US, Australia and New Zealand. Chartered Institute of Management Accountants, 5(7), 1-7.

Kaplan, Robert S., \& David P. N. (1996). Translating Strategy into Action: The Balanced Scorecard. Boston: Harvard Business School Press. 
Koçer, İ. (2007). İşletme ve Organizasyonlarda Stratejik Yönetim Yaklaşımları. Yüksek Lisans Tezi, Marmara Üniversitesi Sosyal Bilimler Enstitüsü, İstanbul.

Koszevska, M. (2004). Outsourcing as a Modern Management Strategy. Prospects for Its Development In The Protecive Clothing Market. AUTEX Research Journal, 4(4), 228-231.

Pasanen, M. (2011). Strategic Management Tools and Techniques in Smes. Society of Interdisciplinary Business Research (SIBR) 2011 Conference on Interdisciplinary Business Research, June 20, 2011. pp. 1-8.

Republic Of Turkey Ministry Of Culture And Tourism. (2011). Retrieved from www.tanitma.gov.tr

Rigby, D. (2001). Management Tools and Techniques: A Survey. California Management Review, 43(2), 139-160.

Şentürk, Faruk K. (2010). Otel İşletmelerinde Stratejik Yönetim Araçları Kullanımı Üzerine Bir Araştırma. Yüksek Lisans Tezi, Akdeniz Üniversitesi Sosyal Bilimler Enstitüsü, Antalya.

Sucu, Mahir E. (2010). KOBİlerde Stratejik Yönetim ve Bir Araştırma. Yüksek Lisans Tezi, Pamukkale Üniversitesi Sosyal Bilimler Enstitüsü, Denizli.

Yılmaz, Mehmet L. (2007). Ilk 500'de Faaliyet Gösteren Konya'daki İsletmelerin Stratejik Yönetime Bakış Açıları, Sorunları ve Çözüm Önerileri. Yüksek Lisans Tezi, Selçuk Üniversitesi Sosyal Bilimler Enstitüsü, Konya. 